\title{
PENGARUH KONSEP DIRI DAN KEBIASAAN BELAJAR TERHADAP HASIL BELAJAR MATEMATIKA SISWA KELAS VIII SMP YP PGRI 4 MAKASSAR
}

\author{
Andi Patimbangi \\ Insitut Agama Islam Negeri Bone, Indonesia \\ andipatimbangi@yahoo.com \\ Finsensius Hendi \\ finsensius.hendi@gmail.com
}

Sekolah Tinggi Keguruan dan Ilmu Pendidikan YPUP Makassar, Indonesia

\begin{abstract}
This research aims to: (1) understand the self-concept of students, habit of students, and students' mathematics learning outcomes, (2) determine how the effects of self-concept on students' mathematics learning outcomes, the influence of learning habit on students' mathematics learning outcomes, the influence of self-concept and learning habit with the students' mathematics learning outcomes.This research wasex-post facto research. The research was conducted in SMP YP PGRI 4 Makassar with sample 40 people. Data collection in this research used question naires and do cumentation. Technique of data analysis used simple linear regression and multiple regressions. The results showed that (1) the concept of self concept of the students, learning habit, and learning outcomes have a tendency in the high category, (2) a significant difference between self concept and mathematics learning outcomes, learning habit with students' mathematics learning outcomes, self concept and learning habit with the learning outcomes of VIII grademath students of SMP YP PGRI 4 Makassar
\end{abstract}

Keywords: self-concept, learning habitandmathematics learningoutcomes.

\section{Pendahuluan}

Kemampuan memanfaatkan dan mengikuti perkembangan serta kemajuan ilmu pengetahuan dan teknologi ditentukan oleh kualitas sumber daya manusia, agar bangsa Indonesia memiliki sumber daya manusia yang berkualitas tinggi. Salah satu wadah kegiatan yang dipandang berfungsi untuk meningkatkan sumber daya manusia adalah pendidikan baik pendidikan jalur sekolah maupun pendidikan luar sekolah.Salah satu mata pelajaran pada jenjang pendidikan jalur sekolah yang dipandang memegang peranan penting dalam upaya penguasaan ilmu pengetahuan dan teknologi adalah matematika. Hal ini disebabkan karena matematika merupakan suatu sarana berpikir logis. Matematika sebagai ilmu pengetahuan yang telah menjadi sarana untuk mengkaji hakekat keilmuan oleh karena itu tidak dapat dipungkiri bahwa kemajuan ilmu pengetahuan dan berpikir matematika.

Menyadari pentingnya peran matematika, maka peningkatan hasil belajar matematika diberbagai jenjang pendidikan format perlu mendapat perhatian yang sungguh-sungguh. Para siswa di semua jenjang pendidikan termasuk SMP dituntut untuk menguasai pelajaran matematika yang hal ini dapat dilihat dengan hasil belajar 
matematika yang tinggi. Matematika berperan sebagai mata pelajaran dasar dan sebagai sarana berpikir ilmiah yang diperlukan siswa untuk mengembangkan kemampuan berpikir logikanya, juga diperlukan untuk penunjang keberhasilan belajar siswa dalam menempuh pendidikan ke jenjang yang lebih tinggi.

Dalam kaitannya dengan usaha peningkatan hasil belajar matematika pemerintah telah melakukan berbagai upaya seperti penyempurnaan kurikulum matematika pengadaan buku paket matematika, peningkatan mutu guru-guru matematika melalui penalaran baik secara regional maupun nasional namun perlu disadari bahwa proses belajar mengajar melibatkan beberapa komponen yang saling mempengaruhi satu sama lain yaitu tujuan yang akan dicapai, siapa yang akan melaksanakan pembelajaran bagaimana cara mengajarkan alat apa yang digunakan serta siapa yang akan belajar dan bagaimana cara belajar yang efektif dan efisien. Ini berarti siswa sendiri ikut menentukan tinggi rendahnya hasil belajar matematika.

Berdasarkan uraian diatas maka peneliti mencoba memilih dua faktor yang sangat berpengaruh terhadap hasil belajar siswa yakni kebiasaan belajar dan konsep diri. Faktorfaktor yang berkaitan dengan siswa tidak sedikit jumlahnya, namun karena keterbatasan peneliti dalam berbagai hal seperti waktu maka penelitian ini dibatasi dalam kajiannya yaitu terbatas pada konsep diri dan kebiasaan belajar. Konsep diri merupakan salah satu konsep efektif yang mempengaruhi pandangan siswa dalam belajar dan hal ini didukung oleh salah penelitian yang dilakukan oleh Supardi yang menemukan bahwa konsep diri merupakan hal penting dalam memberikan efek positif terhadap hasil belajar (Supardi US, 2010)sebab kebiasaan individu memandang dirinya dapat mempengaruhi seluruh perilakunya yang menyimpang di kelas disebabkan pandangan dan sikap negatif terhadap diri sendiri.

Selanjutnya hasil belajar siswa tidak akan berhasil dengan baik apabila tidak mempunyai kebiasaan belajar yang baik karena dalam proses belajarnya siswa tidak hanya menerima pelajaran yang diberikan oleh guru di depan kelas, akan tetapi siswa dituntut untuk memperkaya materi pelajaran. Hal ini diperkuat oleh hasi penelitian yang dilakukan oleh Siagian yang mengemukakan bahwa kebiasaan belajar memiliki pengaruh yang signifikan terhadap hasil belajar (Siagian, 2012). Dengan kerja keras seperti membawa buku. Mengatur waktu belajar, mencatat pelajaran serta menghafal pelajaran.Selain itu hal berdasarkan hasil survey peneliti di lokasi hasil belajar matematika siswa tergolong sedang sehingga peneliti mencoba untuk melihat pengaruh konsep diri dan kebiasaan belajar terhadap hasil belajar matematika.

\section{Hipotesis Penelitian}

Berdasarkan tinjauan pustaka dan kerangka berpikir, maka dirumuskan hipotesis penelitian sebagai berikut :

1. Terdapat pengaruh konsep diri dan kebiasaan belajar secara bersama-sama terhadap hasil belajar matematika.

Dalam pengujian statistik, hipotesis dinyatakan dengan :

$$
\text { Ho: } \beta_{1}=\beta_{2}=0 \quad \text { lawan } \quad \mathrm{H}_{1}: \beta_{1} \neq 0 \text { atau } \beta_{2} \neq 0
$$

2. Konsep diri mempunyai pengaruh positif terhadap hasil belajar matematika, dengan memperhatikan variabel kebiasaan belajar.

Dalam pengujian statistik, hipotesis dinyatakan dengan :

$$
\text { Ho: } \beta_{1}=0 \quad \text { lawan } \quad \mathrm{H}_{1}: \beta_{1}>0
$$


3. Kebiasaan belajar mempunyai pengaruh positif terhadap hasil belajar matematika dengan memperhatikan variabel konsep diri.

Dalam pengujian statistik, hipotesis dinyatakan dengan :

$$
\text { Ho : } \beta_{2}=0 \quad \text { lawan } \quad \mathrm{H}_{1}: \beta_{2}>0
$$

\section{Metode Penelitian}

Penelitian ini adalah penelitianex-post facto yang bersifat korelasional. Disebut ex-post facto karena fakta yang dikumpulkan sudah ada pada populasi sebelum penelitian dilakukan. Bersifat regresional karena menyelidiki pengaruh antara variabel dalam hal ini ada dua variabel yaitu variabel tak bebas dan variabel bebas. Variabel tak bebas yang diselidiki adalah hasil belajar matematika dan variabel bebasnya terdiri dari dua yaitu konsep diri dan cara belajar. berikut :

Disain hubungan antara variabel-variabel penelitian dapat dilihat seperti model

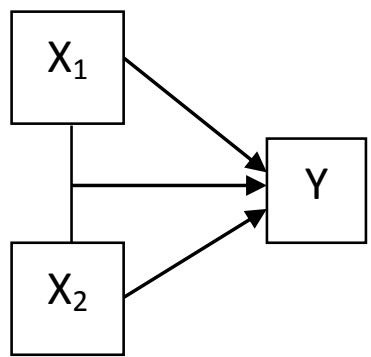

Keterangan :

$\mathrm{X}_{1}=$ konsep diri

$\mathrm{X}_{2}=$ kebiasaan belajar

$\mathrm{Y}=$ hasil belajar matematika

\section{Populasi Dan Sampel}

Penelitian ini dilaksanakan di SMP YP-PGRI 4 populasi penelitian ini adalah siswa kelas VIII SMP YP-PGRI 4. Langkah-langkah yang ditempuh dalam penentuan sampel penelitian ini adalah sebagai berikut :

1. Mengidentifikasikan semua kelas VIII SMP YP PGRI 4 yang terdiri atas 2 kelas.

2. Memilih seluruh siswa dari dua kelas, sebagai sampel penuh karena jumlah populasi kurang dari 100 orang.

3. Siswa dari dua kelas sebanyak 69 orang (siswa kelas VIII A sebanyak 34 orang dan siswa kelas VIIIB sebanyak 35 orang) yang merupakan populasi penelitian. Dari 69 diambil 40 orang siswa sebagai sampel penelitian

\section{Definisi Operasional Variabel}

1. Hasil belajar matematika

Hasil belajar yang dimaksud disini kemampuan dalam aspek kognitif yang mencakup 3 aspek, yaitu kemampuan ingatan $\left(\mathrm{C}_{1}\right)$. Kemampuan pemahaman $\left(\mathrm{C}_{2}\right)$, kemampuan penerapan $\left(\mathrm{C}_{3}\right)$ yang skornya adalah nilai semester genap tahun pelajaran 2010 / 2011.

2. Konsep Diri

Konsep diri yang dimaksud disini adalah konsep diri matematika yang dimiliki siswa yang indikatornya, yaitu: (a) persepsi terhadap pelajaran matematika; (b) harapan terhadap pelajaran matematika; (c) perasaan terhadap pelajaran matematika, dan (d) kesediaan untuk belajar matematika yang skornya diperoleh dengan menggunakan skala penilaian konsep diri.

3. Kebiasaan Belajar 
Kebiasaan belajaryang dimaksud disini adalah cara belajar matematika yang sering dilakukan oleh siswa yang indikatornya yaitu: (a) cara mengikuti pelajaran di kelas; (b) cara mengatur waktu; (c) cara membaca buku; (d) cara membuat ringkasan; (e) cara menghafal pelajaran, dan (f) cara menempuh ujian, yang skornya diperoleh dengan menggunakan skala penilaian kebiasaan belajar.

\section{Teknik Pengumpulan Data}

Jenis data yang akan dikumpulkan termasuk data kuantitatif. Teknik pengumpulan data yang digunakan dalam penelitian ini, yaitu :

1. Data hasil belajar matematika

Data hasil belajar matematika merupakan data dokumentasi yang diambil dari nilai mid semester ganjil siswa kelas VIII SMP YP PGRI 4 Makassar.

2. Data konsep diri dan kebiasaan belajar matematika

Data dari kedua variabel diatas diperoleh dengan menggunakan skala penilaian yang siap pakai kepada masing-masing responden. Ada 2 macam skala penilaian yang digunakan yaitu skala konsep diri matematika dan skala kebiasaan belajar matematika.

\section{Instrumen Penelitian}

Untuk memperoleh data dari masing-masing vaeiabel, peneliti menggunakan dua jenis instrument yaitu konsep diri matematika dan kebiasaan belajar matematika sedangkan untuk hasil tidak dibuatkan instrumen tetapi dari nilai semester.

1. Konsep Diri matematika

Skala penilaian konsep diri matematika yang digunakan dalam penelitian ini adalah kuesioner yang telah dikembangkan dan ujicobakan oleh Mappaita (1994) dalam penelitiannya yang berjudul "hubungan konsep diri matematika dan motivasi berprestasi belajar matematika siswa-siswi kelas I SMA negeri kotamadya Ujungpandang” untuk mengetahui karakteristik dari masing-masing item skala penilaian konsep diri matematika tersebut oleh yang mengembangkan instrument telah dilakukan ujicoba dengan koefisien reliabilitas sebesar 0,943. Skala penilaian konsep diri tersebut terdiri atas 40 butir pernyataan. Instrument ini berbentuk skala penilaian model "Likert" dengan lima alternatif jawaban yaitu sangat sesuai (SS), sesuai (S), samar-samar (R), tidak sesuai (TS), dan sangat tidak sesuai (STS).

Skala penilaian ini terdiri atas dua jenis pernyataan, yaitu pernyataan positif dan pernyataan negatif. Untuk pernyataan positif skornya adalah sangat sesuai $=5$, sesuai $=4$, samar-samar $=3$, tidak sesuai $=2$, dan sangat tidak sesuai $=1$. Sedang untuk pernyataan negatif skornya adalah sebaliknya. Jumlah skor keseluruhan item untuk masing-masing responden menyatakan skor yang dicapai oleh responden tersebut.

2. Kebiasaan Belajar matematika

Skala penilaian kebiasaan belajar matematika yang digunakan dalam penilaian ini adalah skala penilaian yang telah dikembangkan oleh Tety (1990) dalam penelitiannya yang berjudul "Pengaruh Cara Belajar Dan Motivasi Berprestasi Terhadap Prestasi Belajar Matematika Siswa SMA di Sulawesi Selatan.

Skala penilaian ini disusun berdasarkan 6 indikator cara dan kebiasaan belajar. Untuk mengetahui karakteristik dari masing-masing item skala ini, oleh yang mengembangkan telah dilakukan uji coba dengan koefisien reliabilitas yang di dapat sebesar 0,821 dengan junlah item 48 item pertanyaan. Alat ukur tersebut terdiri atas 5 
alternatif jawaban, yaitu tidak pernah melakukan, dan selalu atau sangat sering melakukan.

Instrument kebiasaan belajar terdiri atas dua jenis pernyataan, yaitu pernyataan positif dan pernyataan negatif .untuk pernyataan positif skornya adalah : tidak pernah melakukan $=1$, jarang melakukan $=2$, kadang-kadang melakukan $=3$, sering melakukan $=4$ dan sangat sering melakukan $=5$. Sedang untuk pernyataan negative skornya adalah sebaliknya. Junlah skor keseluruhan item untuk masing-masing responden menyatakan skor yang dicapai oleh responden tersebut.

Kriteria yang digunakan untuk menentukan kategori skor konsep diri dan kebiasaan belajar dibuat berdasarkan "method of summated rating" atau metode penilaian yang dijunlahkan titik tengah dari skor total masing-masing kategori jawaban merupakan batas-batas interval kategori sifat ilmiah. Menurut Sappaile (1998:29) penentuan batasbatas kategori diperoleh dengan langkah-langkah sebagai berikut :

1) menjumlahkan skor untuk tiap-tiap kategori berdasarkan skor dari hasil pembobotan.

2) menanai bilangan-bilangan dari hasil penjumlahan pada garis bilangan.

3) menentukan titik tengah dari setiap dua bilangan yang berurutan. Titik tengah yang diperoleh pada lampiran $\mathrm{C}$ masing-masing untuk skala penilaian konsep diri adalah 25,$4 ; 70,0 ; 108.8 ; 152,05$. Titik tengah untuk skor kebiasaan belajar adalah 23,65; 66,$15 ; 103,0 ; 142,1$.

Garis bilangan yang dimaksud di atas adalah sebagai berikut :

1. Skala penilaian konsep diri matematika

\begin{tabular}{l|l|l|l|r}
\multicolumn{2}{c}{25,4} & 70,0 & 108,8 & 152.05 \\
\hline 0,00 & 50,8 & 89,2 & 128,4 & 175,7
\end{tabular}

Berdasarkan uraian di atas, diperoleh interval kategori senagai berikut untuk menentukan konsep diri siswa sebagai berikut :

$0,0<$ konsep diri $<25,4$ dikategorikan sangat rendah

$25,4<$ konsep diri $<70,0$ dikategorikan rendah

$70,0<$ konsep diri $<108,8$ dikategorikan sedang

$108.8<$ konsep diri < 175,7 dikategorikan sangat tinggi

2. Angkat cara belajar matematika

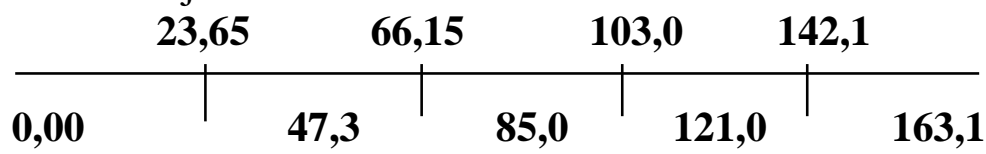

Berdasarkan uraian di atas, diperoleh interval kategorisasi sebagai kriteria untuk menentukan konsep diri siswa sebagai berikut :

$0,00<$ konsep belajar $<23,65$ dikategorikan sangat rendah

$23,65<$ konsep belajar $<66,15$ dikategorikan rendah

$66,15<$ konsep belajar < dikategorikan sedang

$103,0<$ konsep belajar < dikategorikan tinggi

$142,1<$ konsep belajar < dikategorikan sangat tinggi 


\section{Teknik Analisis Data}

Data yang diperoleh dari sampel penelitian berupa skor konsep diri matematika skor kebiasaan belajar, dan skor hasil belajar matematika, dianalisis dengan menggunakan dua jenis statistika, yaitu statistika deskriptif dan statistik infrensial. Statistik deskriptif digunakan untuk mendeskripsikan karakteristik skor responden. Untuk keperluan tersebut digunakan tabel frekuensi, rata-rata dan standar deviasi. Analisis statistik inferensial digunakan untuk menguji hipotesis penelitian. Untuk keperluan tersebut, digunakan analisis regresi linear ganda. Sebelum pengujian hipotesis dengan statistik inferensial, maka terlebih dahulu dilakukan uji persyaratan analisis yaitu uji normalitas dan uji linearitas regresi.

Model regresi yang digunakan dalam penelitian ini adalah regresi linear ganda dengan dua variabel bebas, (Ghozali, 2006)dengan model :

$$
\begin{aligned}
& \bar{y}=\beta o+\beta_{1} \mathrm{X}_{1} \\
& \beta_{0}=\frac{\left(\sum x_{1}^{2}\right)-\left(\sum x_{1}\right)\left(\sum x_{1} \mathrm{y}\right)}{\mathrm{n}\left(\sum x_{1}^{2}\right)-\left(\sum x_{1}\right)^{2}} \\
& \beta_{1}=\frac{n\left(\sum x_{1} y\right)-\sum x_{1} \mathrm{y}}{\mathrm{n}\left(\sum x_{1}^{2}\right)-\left(\sum x_{1}\right)^{2}} \\
& \bar{y}=\beta o+\beta_{2} \mathrm{X}_{2} \\
& \left(\sum Y\right)\left(\sum x_{1}^{2}\right)-\left(\sum x_{1}\right)\left(\sum x_{1} \mathrm{y}\right) \\
& \beta_{o}=\frac{n\left(\sum x_{1}^{2}\right)-\left(\sum x_{1}\right)^{2}}{n\left(\sum x_{1} y\right)-\sum x_{1} \mathrm{y}} \\
& \beta_{1}=\frac{n\left(\sum x_{2}^{2}\right)-\left(\sum x_{2}\right)^{2}}{\bar{y}=} \beta o+\beta x_{1}+\beta_{2} \mathrm{x}_{2}+\varepsilon \\
& \bar{y}=\beta o+\beta_{1} \mathrm{x}_{1}+\beta_{1} \mathrm{x}_{2}+\varepsilon
\end{aligned}
$$

$$
\begin{array}{lll}
\text { Keterangan } & \bar{y} & =\text { Skor prestasi belajar siswa } \\
& \mathrm{X}_{1} & =\text { Skor sikap siswa } \\
\mathrm{X}_{2} & =\text { Skor kebiasaan belajar matematika } \\
\beta \mathrm{o}, \beta_{1}, \beta_{2} & =\text { Parameter yang akan digunakan } \\
\varepsilon & =\text { Kesalahan acak }
\end{array}
$$

Sedangkan model fungsi taksiran adalah :

$\bar{y}=\beta o+\beta_{1} x_{1}+\beta_{1} x_{2}$ 
Keterangan :

$$
\begin{aligned}
& \bar{y}=\text { Penaksiran } Y \\
& \mathrm{~b}_{0}=\text { Penaksiran } \beta \mathrm{o} \\
& \mathrm{b}_{1}=\text { Penaksiran } \beta_{1} \\
& \mathrm{~b}_{2}=\text { Penaksiran } \beta_{2}
\end{aligned}
$$

\section{Hasil dan Pembahasan}

1. Hasil Analisis Statistik Deskriptif

Hasil analisis statistik deskriptif menunjukkan deskripsi tentang karakteristik dari masing-masing variabel penelitian dan sekaligus merupakan jawaban terhadap pertanyaan yang dirumuskan dalam penelitian.

a. Variabel Konsep Diri Matematika $\left(\mathrm{X}_{1}\right)$

Hasil analisis statistik deskriptif yang berkaitan dengan skor variabel konsep diri matematika dapat dilihat pada rangkuman yang disajikan pada tabel 1 berikut.

Tabel 1. Statistik deskriptif skor variabel konsep diri matematika

\begin{tabular}{|l|c|}
\hline \multicolumn{1}{|c|}{ Statistik } & Nilai Statistik \\
\hline Ukuran Sampel & 40 \\
Skor tertinggi & 199 \\
Skor terendah & 65 \\
Rentang Skor(range) & 134 \\
Skor rata-rata (mean) & 127,8250 \\
Simpangan baku & 19,75346 \\
(Standar Deviasi) & \\
\hline
\end{tabular}

Apabila skor variabel konsep diri matematika di kelompokkan dalam lima kategori, maka diperoleh distribusi frekuensi dan persentase skor seperti yang telah ditunjukan pada tabel 2 berikut ini.

Tabel 2.Frekuensi pada presentase skor konsep diri matematika $\left(\mathrm{X}_{1}\right)$

\begin{tabular}{|l|c|c|c|}
\hline \multicolumn{1}{|c|}{ Skor } & Kategori & Frekuensi & Presentase \\
\hline $0-40$ & Sangat rendah & 0 & 0 \\
$41-80$ & Rendah & 1 & $2,5 \%$ \\
$81-120$ & Sedang & 12 & $30 \%$ \\
$121-160$ & Tinggi & 25 & 62,55 \\
$161-200 \quad$ & Sangat tinggi & 2 & $50 \%$ \\
\hline \multicolumn{2}{|c|}{ Jumlah } & 40 & 100 \\
\hline
\end{tabular}

Dengan mengacu pada tabel 1 dan tabel2 dapat dinyatakan bahwa pada umumnya konsep diri matematika siswa-siswa kelas VIII SMP YP-PGRI 4 Makassar secara umum tergolong dalam kategori tinggi.

b. Variabel kebiasaan belajar matematika $\left(\mathrm{X}_{2}\right)$

Hasil analisis statistik deskriptif yang berkaitan dengan skor variabel kebiasaan belajar matematika dapat dilihat pada rangkumanyang disajikan dalam tabel 3 berikut ini. 
Tabel. 3 Statistik deskriptif skor variabel kebiasaan belajar

\begin{tabular}{|l|c|}
\hline \multicolumn{1}{|c|}{ Statistik } & Nilai Statistik \\
\hline Ukuran Sampel & 40 \\
Skor tertinggi & 83 \\
Skor terendah & 40 \\
Rentang Skor(range) & 43 \\
Skor rata-rata (mean) & 63,7 \\
Simpangan baku & 11,36659 \\
\hline
\end{tabular}

Apabila skor variabel kebiasaan belajar di kelompokan dalam lima kategori, maka diperoleh distribusi frekuensi dan presentase skor seperti yang telah ditunjukan pada tabel4 berikut ini.

Tabel 4. Frekuensi dan presentase skor variabel kebiasaan belajar matematika.

\begin{tabular}{|c|c|c|c|}
\hline Skor & Kategori & Frekuensi & Presentase \\
\hline $0-35$ & Sangat rendah & 0 & 0 \\
$35-54$ & Rendah & 9 & $22,5 \%$ \\
$55-64$ & Sedang & 11 & $27,5 \%$ \\
$65-84$ & Tinggi & 20 & $50 \%$ \\
$85-100$ & Sangat tinggi & & 0 \\
\hline \multicolumn{2}{|c|}{ Jumlah } & 40 & 100 \\
\hline
\end{tabular}

Tabel 4 menunjukan bahwa $50 \%$ siswa memiliki kebiasaan belajar dalam kategori tinggi yaitu dalam interval $65-84$ dengan demikian dapat dinyatakan bahwa pada umumnya kebiasaan belajar siswa-siswa kelas VIII SMP YP-PGRI 4 Makassar.

c. Variabel Hasil belajar Matematika (Y)

Hasil analisis statistika deskriptif yang berhubungan dengan skor variabel hasil belajar matematika dapat dilihat pada rangkumanyang disajikan pada tabel5 berikut ini.

Tabel 5 Statistika Desriptif Skor hasil belajar matematika (Y)

\begin{tabular}{|l|c|}
\hline \multicolumn{1}{|c|}{ Statistik } & Nilai Statistik \\
\hline Ukuran Sampel & 40 \\
Skor tertinggi & 85 \\
Skor terendah & 55 \\
Rentang Skor(range) & 30 \\
Skor rata-rata (mean) & 68,25 \\
Simpangan baku & 8,74 \\
(Standar Deviasi) & \\
\hline
\end{tabular}

Berdasarkan nilai semester genap yang diambil untuk mengukur hasil belajar matematika skor maksimum yang mungkin dicapai oleh siswa adalah 10 dengan mengelompokkan skor dalam lima kategori berdasarkan edaran Direktorat Pendidikan menengah umum N0. 299/C3/MN/ 99, maka diperoleh distribusi frekuensi yang ditunjukan pada tabel dibawah ini. 
Tabel 6. Frekuensi dan presentase skor variabel hasil belajar matematika

\begin{tabular}{|c|c|c|c|}
\hline Skor & Kategori & Frekuensi & Presentase \\
\hline $0-35$ & Sangat rendah & 0 & 0 \\
$35-54$ & Rendah & 0 & 0 \\
$55-64$ & Sedang & 11 & $27,5 \%$ \\
$65-84$ & Tinggi & 24 & $60 \%$ \\
$85-100$ & Sangat tinggi & 5 & 12,5 \\
\hline \multicolumn{2}{|c|}{ Jumlah } & 40 & 100 \\
\hline
\end{tabular}

Tabel 6 dengan memperhatikan 40 siswa sebagai sampel , 29 siswa atau 72,5\% memiliki kategori tinggi keatas dengan skor rata-rata 68,25 dan standar deviasi 8,63 dengan demikian dapat disimpulkan bahwa hasil belajar matematika siswa kelas VIII SMP YP-PGRI 4 Makassar secara umum dalam kategori tinggi.

2. Hasil Analisis Statistik Inferensial

Sebelum pengujian hipotesis penelitian dilakukan analisis regresi. Data yang digunakan adalah skor dari ketiga variabel $\mathrm{X}_{1}, \mathrm{X}_{2}$ dan $\mathrm{Y}$ dengan variabel konsep diri $\left(\mathrm{X}_{1}\right)$, kebiasaan belajar $\left(\mathrm{X}_{2}\right)$, dan variabel hasil belajar matematika $(\mathrm{Y})$, maka regresi yang dilakukan adalah regresi $\mathrm{Y}$ atas $\mathrm{X}_{1}$ dan $\mathrm{X}_{2}$. Hal ini dilakukan untuk menguji hipotesis penelitian.

Adapun kriteria persyaratan analisis terlebih dahulu diperiksa multikolineritas, normalitas dan independensi. Hasil analisis data menunjukkan ketiga uji prasyarat tersebut memenuhi sehingga dapat dilanjutkan pada analisis regresi.Berdasarkan hasil analisis dengan menggunakan regresi linear ganda diperolehpersamaan regresiY = $27.865+0,677 \mathrm{X}_{1}+0,021 \mathrm{X}_{2}$.Selanjutnya pengujian hipotesis dilakukan dengan bantuan SPSS, pengujian dari ketiga rumusan hipotesis penelitian adalah sebagai berikut.

Pengujian Hipotesis

Pengujian hipotesis dilakukan dengan bantuan program SPSS. Selanjutnya dari ketiga rumusan hipotesis penelitian adalah sebagai berikut :

a. Hipotesis dinyatakan dengan :
Ho : $\beta_{1}=B_{2}=0$
lawan
Ho $\neq B_{1}=B_{2} \neq 0$

kriteria penolakan Ho jika $\mathrm{p}<\alpha$ sehingga $\mathrm{Ho}$ ditolak dan $\mathrm{H}_{1}$ diterima atau $\mathrm{F}$ hitung $>\mathrm{F}$ tabel. Berdasarkan hasil perhitungan diperoleh nilai $\mathrm{p}=0,000$ yang kurang dari pada taraf signifikansi $\alpha=0,05$, berarti $\mathrm{H}_{0}$ ditolak maka $\mathrm{H}_{1}$ yang diterima atau $\mathrm{F}$ hitung $=41,68>\mathrm{F}$ tabel $=3,20$ sehingga $\mathrm{H} 0$ ditolak dan $\mathrm{H}_{1}$ diterima. jadi secara statistik dapat disimpulkan bahwa konsep diri dan kebiasaan belajar secara bersama-sama berpengaruh positif terhadap hasil belajar matematika.

b. Hipotesis dinyatakan dengan :
Ho $: \beta_{1}=0$
lawan
Ho : $\beta_{1} \neq 0$

kriteris penolakan Ho jika $\mathrm{p}<\alpha$ sehingga Ho ditolak dan $\mathrm{H}_{1}$ diterima. Berdasarkan hasil perhitungan diperoleh nilai $\mathrm{p}=0,000$ yang kurang dari $\alpha=$ 0,05 berarti Ho ditolak maka $\mathrm{H}_{1}$ diterima

Jadi dapat disimpulkan bahwa terdapat pengaruh konsep diri terhadap hasil belajar matematika dengan memperhatikan kebiasaan belajar.

c. Hipotesia dinyatakan dengan :
Ho : $\beta_{2}=0$
lawan
Ho : $\beta_{1}>0$ 
kriteria penolakan Ho jika $\mathrm{p}<\alpha$ sehingga Ho ditolak dan $\mathrm{H}_{1}$ diterima.Hasil perhitungan diperoleh nilai $\mathrm{p}=0,000$ yang kurang dari pada taraf signifikasi $\alpha=$ 0,05, berarti Ho ditolak maka $\mathrm{H}_{1}$ diterima.

Jadi dapat disimpulkan bahwa terdapat pengaruh kebiasaan belajar terhadap hasil belajar matematika.

Besarnya variansi hasil belajar matematika yang dapat ditentukan oleh konsep diri dan kebiasaan belajar secara bersama-sama yang dapat dilihat dari koefisien determinasi atau koefisien penentu $\left(\mathrm{R}^{2}\right)$. Dari hasil analisis diperoleh $\mathrm{R}^{2}=0,785$ dengan demikian $78,5 \%$ variansi hasil belajar matematika dapat ditentukan oleh konsep diri dan kebiasaan belajar matematika secara bersama-sama.

2. Pembahasan hasil penelitian

Hasil penelitian menunjukkan bahwa ada pengaruh yang signifikan antara konsep diri dan kebiasaan belajar terhadap hasil belajar matematika. Secara individual konsep diri memberikan pengaruh yang positif terhadap hasil belajar matematika. Hal ini sesuai dengan pendapat ahli yang menyatakan bahwa demi tercapainya hasil belajar yang baik, maka belajar sebagai proses yang terpadu melibatkan beberapa komponen, seperti peserta didik yang memiliki IQ, minat, bakat, faktor psikologis yang baik, kemampuan, motivasi, sikap, kematangan, disiplin, konsep diri dan lain-lain. Selain itu hasil penelitian ini juga sejalan dengan hasil penelitian Mappaita yang menyimpulkan bahwa konsep diri matematika dan jenis kelamin siswa (tanpa memperhitungka variabel yang lain) secara bersama-sama mempunyai hubungan (pengaruh) positif terhadap prestasi belajar matematika siswa SMA se Sulawesi Selatan.

Untuk variabel kebiasaan belajar, menurut hasil penelitian diperoleh bahwa kebiasaan belajar memberikan pengaruh yang signifikan terhadap hasil belajar matematika. Hal ini sesuai dengan pendapat Syah (2010) yang menyatakan bahwa kebiasaan belajar akan bardampak terhadap ranah kognitif siswa. Jika siswa membiasakan diri untuk kebiasaan yang baik maka akan berdampak positif pula terhadap hasil belajar siswa. Dan sebaliknya jika siswa terbiasa dengan kebiasaan yang kurang baik maka akan berdampak negatif juga terhadap hasil belajar siswa. Pembentukan kebiasaan belajar yang baik dapat dilakukan dengan cara belajar dan latihan dalam jangka waktu yang singkat tetapi dilakukan secara berulang-ulang, yaitu dengan belajar secara mandiri ataupun kelompok di luar jam pelajaran sekolah, memperhatikan ketika guru menerangkan, dan menghadapi ujian dengan cara-cara yang baik.

Secara bersamaan konsep diri dan kebiasaan belajar memberikan pengaruh positif terhadap hasil belajar matematika dengan kontribusi sebesar 78,5\%. Hal ini sesuai dengan pendapat (Sudjana, 2009)yang menyatakan bahwa hasil belajar yang dicapai siswa dipengaruhi oleh dua faktor utama yaitu faktor dari dalam diri siswa (internal) dan faktor dari luar diri siswa (eksternal). Faktor dari dalam diri siswa adalah faktor kemampuan yang dimiliki oleh siswa, sedangkan faktor dari luar diri siswa seperti motivasi belajar, minat dan perhatian, konsep diri, intelejensi, sikap dan kebiasaan belajar.

Berdasarkan uraian diatas, dapat disimpulkan bahwa konsep diri dan kebiasaan belajar merupakan faktor yang mempengaruhi hasil belajar seseorang. Konsep diri dan kebiasaan belajar merupakan faktor eksternal yang dapat diperoleh karena proses yang berulang-ulang. Dalam hal kebiasaan belajar siswa dapat membiasakan diri untuk mengembangkan kebiasaan belajar yang baik, baik kebiasaan belajar di sekolah, di rumah secara mandiri, dalam kelompok, maupun dalam menghadapi ujian ulangan, ujian MID, dan UAS. 


\section{Simpulan}

Berdasarkan analisis data dan pembahasan, maka dapat diambil kesimpulan sebagai berikut : 1) hasil belajar matematika siswa kelas VIII SMP YP PGRI 4 makassar secara umum memiliki kecenderungan dalam kategori tinggi; 2). konsep diri matematika siswa kelas VIII YP PGRI 4 memiliki kecenderungan dalam kategori tinggi; 3)kebiasaan belajar matematika siswa kelas VIII SMP YP PGRI 4 Makassar memiliki kecenderungan dalam kategori sedang; 4) konsep diri dan kebiasaan belajar secara bersama-sama mempunyai pengaruh terhadap hasil belajar matematika siswa kelas VIII SMP YP PGRI 4 Makassar taraf signifikansi $\alpha=0,05$; 5) konsep diri mempunyai pengaruh positif terhadap hasil belajar matematika siswa VIII SMP YP PGRI 4 Makassar pada taraf signifikansi $\alpha=0,05$; dan 6) kebiasaan belajar berpengaruh positif terhadap hasil belajar matematika siswa kelas VIII SMP YP PGRI 4 Makassar pada taraf signifikansi $\alpha=0,05$.

\section{Daftar Pustaka}

Ahmad Abu, 1990. Tehnik Belajar Yang Efektif, Jakarta Rineka Cipta.

A Siregar Tetty. 1990. Pengaruh cara belajar dan motivasi berprestasi terhadap prestasi belajar matematika siswa SMA di Sulawesi Selatan Ujung Pandang. Lembaga Penelitian IKIP Ujung Pandang.

Djaali 1987. Pengaruh Kebiasaan Belajar Sikap Kemampuan Dasar Dan Proses Belajar Mengajar Terhadap Prestasi Belajar Matematika Siswa SLTP Di Sulawesi Selatan Di Luar Kotamadya Ujungpandang (Laporan Penelitian) Ujungpandang P4M Dirjen Dikti.

Erni Suandi, 2002. Belajar dan faktor-faktor yang mempengaruhinya. Jakarta Rinneka Cipta.

Ghozali, I. (2006). Analisis Multivariate Lanjutan dengan Program SPSS.

Hodoyo Herman 1990. Strategi Belajar Mengajar Matematika Jakarta Depdikbud.

Muhammad Mappaita, 1994. Hubungan Konsep Diri Mathematical Dan Motivasi Berprestasi Belajar Matematika Siswa-Siswa Kelas I SMA Negeri Di Kotamadya Ujung Pandang. Tesis Dosen Fakultas Pasca Sarjana Ikip Malang.

Pudjijogyanti, Clara R, 1995, Konsep Diri Dalam Pendidikan, Jakarta ;Arcan.

Sappaile, 1958. Kebiasaan Belajar. Choco Theme by.css\{mayo\}| powored by WordPress Entries (RSS) and Comments (RSS)

Semiati Ibnu Umar, 1993. Faktor-faktor Yang Mempengaruhi Proses Belajar Mengajar dan Praktek Belajar. Dirjen Dikti Projek NNK, Jakarta.

Slamento, 1993. Belajar dan Faktor-faktor Mempengaruhinya. Jakarta Rineka Cipta.

Siagian, R. E. F. (2012). Pengaruh Minat dan Kebiasaan Belajar Siswa Terhadap Prestasi

Belajar Matematika. Jurnal Formatif. https://doi.org/http://journal.lppmunindra .ac.id/index.php/Formatif/article/viewFile/750/659

Sudjana, N. (2009). Penilaian Hasil Proses Belajar Mengajar. Sinarbaru. https://doi.org/ 10.1016/j.talanta.2011.10.012

Supardi US, L. \&. (2010). Pengaruh Konsep Diri, Sikap Siswa pada Matematika, dan

Kecemasan Siswa terhadap Hasil Belajar Matematika. Jurnal Cakrawala

Pendidikan. https://doi.org/10.21831/cp.v3i3.362

Tety, 1990. Cara Belajar Yang Tidak berpengaruh Terhadap belajar Matematika. Skripsi UNM Makassar jurusan Matematika 2009. 